\title{
Collaboration Across Borders, or Piiride-ülene Koostöö: Estonians and Americans Working Together Towards Accessible Archival Collections
}

\section{Ellen Engseth \& Gristel Ramler}

To cite this article: Ellen Engseth \& Gristel Ramler (2019) Collaboration Across Borders, or Piiride-ülene Koostöö: Estonians and Americans Working Together Towards Accessible Archival Collections, Journal of Library Administration, 59:5, 565-577, DOI: 10.1080/01930826.2019.1616972

To link to this article: https://doi.org/10.1080/01930826.2019.1616972

曲 Published online: 19 Jun 2019.

Submit your article to this journal $\llbracket$

Џ Article views: 59

Q View related articles ¿ત

View Crossmark data $[7$ 


\title{
Global Perspectives
}

\author{
PEGGY NZOMO, Column Editor \\ Global Education Librarian, Kent State University, Kent, OH, USA
}

\begin{abstract}
Column Editor's Note. The "Global Perspectives" column gathers views on current topics of global interest from authors worldwide. Contributions from across the globe are valued and encouraged as they add a richness that is the voice of today's global information infrastructure. Interested authors are invited to contact the column editor at pnzomo@kent.edu.
\end{abstract}

\section{COLLABORATION ACROSS BORDERS, OR PIIRIDE-ÜLENE KOOSTÖÖ: ESTONIANS AND AMERICANS WORKING TOGETHER TOWARDS ACCESSIBLE ARCHIVAL COLLECTIONS \\ ELLEN ENGSETH}

Lead Author, Curator of the Immigration History Research Center Archives and Head of Migration and Social Services Collections, University of Minnesota Libraries, Minneapolis, $M N, U S A$

\section{GRISTEL RAMLER}

Deputy Head, Acquisition Department in Tallinn, Head of Private Archives Services and Content and Description Services, National Archives of Estonia, Tallinn, Estonia

ABSTRACT. A collaborative project to improve global description and thus discovery of library material is shared and analyzed

(C) The Author(s)

Address correspondence to Ellen Engseth, Lead Author, Curator of the Immigration History Research Center Archives and Head of Migration and Social Services Collections, University of Minnesota Libraries, University of Minnesota, 311 Andersen Library, 222 21st Avenue South, Minneapolis, MN 55455, USA. E-mail: eengseth@umn.edu

Color versions of one or more of the figures in the article can be found online at www.tandfonline.com/wjla.

This article has been republished with minor changes. These changes do not impact the academic content of the article. 
after a decade of activity. The Immigration History Research Center Archives and the National Archives of Estonia work together to arrange and describe archival collections, utilizing the assets of the two different institutions. This project recognizes that the unique research material located in Minnesota bolds importance to patrons in many countries, are a result of cultural and informational migration, and that access to this multilingual source material relies on robust description. The article provides the project's context, and describes its administration.

KEYWORDS access, archives, collaboration, discoverability, international, libraries, metadata, multilingual, staffing

\section{INTRODUCTION}

A collaborative project between the Immigration History Research Center Archives at the University of Minnesota Libraries and the National Archives of Estonia now spans a decade, and provides a model for improving multicountry discovery of unique materials. While the goals and objectives of the project are many, varied, and evolving, its formative goal of discoverability continues to drive the project. This project recognizes that the unique research and archival material located in Minnesota holds importance to patrons in many countries, are a result of cultural and informational migration, and that access to this multilingual source material begins with robust description. This "Estonia Minnesota project," when located within the landscape of archival and library international initiatives, shares characteristics with others. Yet it is born from distinct needs resulting from migration and diaspora, and is a model expressly oriented to metadata, description and improving access points in order to benefit worldwide users. In this project, Estonian archivists travel to Minnesota to share their skills and expertise with the American counterparts, and the partnering institutions together provide administration, funding, and infrastructure. The purpose of this article is to share the projects' genesis, structure and process, and its continuing rationale from a management perspective.

\section{LITERATURE REVIEW}

The English-language professional journal literature on library or archival international collaborative projects is, understandably, broad and varied. 
Recent literature reveals a field affected by the forces of globalization, as well as a broad shift from a focus on the local towards the global. Longstanding interest to share metadata, expertise, and special source material now meet the extra-professional forces such as globalization and public expectation for fast access to information, including digital surrogates and effective search portals. Much of the existing literature centers on themes of information exchange (including metadata and digital content), staff exchange and training, and administrative relationships encouraged by larger civic or university partnerships.

Information exchange has of course been occurring since collegial international discussions first began, and associations (e.g., the International Federation of Library Association founded in 1927 and the International Council on Archives founded in 1948) helped to develop these. Recent literature revolves around the possibilities afforded by newer technologies, such as federated or collaborative digital projects and content, and the standardization and exchange of structured data (Asencio, 2017; Farrugia, 2018; Matusiak, 2017). Staff training and development, often to build global competencies or library-specific skills, also populate the recent journal literature (Li \& Pan, 2018; Smith, 2016; Somerville, Cooper, Torhell, \& Hashert, 2015). And formal partnerships are developed by libraries of all kinds to support internal interests such as acquisitions, or to support wider civic or institutional initiatives such as the internationalization of universities (Mattson \& Hickok, 2018; Somerville et al., 2015). A smaller set of library and information studies (LIS) journal literature recognizes the longstanding and recent attention to genealogy, and to cultural heritage and diasporic memory sources affecting libraries and archives (Farrugia, 2018; Little, 2007; Noorhani, 2008; Wurl, 2005).

Yet management concerns such as budget, personnel, planning, and strategy are only occasionally discussed within this journal literature (Smith, 2015). Jihua (2015), for example, provides rationale and vision for international exhibit collaboration, and Farrugia (2018) discusses management concerns while presenting a model and setting it in a broader context. This case study on the Estonia Minnesota project contributes to the small corpus of those discussing administrative and managerial elements involved in international collaborative projects, and to the even smaller corpus of discussion of the distinct needs resulting from the migration and diaspora of people and the unique source material created by them. Among archival literature, Farrugia, for example, recognizes the importance of "the protection of the collective memories of diasporic communities living far from their homeland" (p. 115). Yakel (1992) described a transnational, multilingual effort to describe archival records in order to improve global access points, and Evans (1987) provided a useful survey of access-oriented international collaborative projects. This article 
strengthens this area of LIS literature, presenting the administrative perspective of an ongoing and current project.

\section{CASE STUDY}

The Estonia Minnesota project aims to improve the discoverability of, and thus improve access to, archival and manuscript collections pertaining to Estonian Americans, written in many languages, and located at the University of Minnesota Libraries. Discoverability of archival sources is improved when tools such as collection guides provide summary or detailed information on collections, creators, and contexts. These guides then serve as access points into the original source material, and increasingly are searchable through web-based discoverability systems. The specialized archival function of "processing", often referred to as arrangement and description, typically results in some type of collection guide in the U.S. The principles of archival processing in Estonia are very similar since their Archives $\mathrm{Act}^{2}$ and Archival Rules ${ }^{3}$ mandate that archival descriptions be based on General International Standard Archival Description (the $\operatorname{ISAD}(G))^{4}$ approved by the International Council on Archives. Since 2009, 11 Estonian archivists have visited Minnesota in 8 trips, collaborating with Minnesota staff to process (arrange and describe) more than 350 collections of personal papers and organizational records. The resulting Englishlanguage description, or metadata, ensures their discoverability via Minnesota platforms and general search engines. Both partners also enjoy other benefits, such as skill building, and the increased intellectual and physical control of this rare and unique material. The latter is particularly important to the host institution in Minnesota, the Immigration History Research Center Archives.

The Immigration History Research Center Archives (IHRCA) is an archive and special library for the study of immigration, ethnicity, and race. It is part of the Archives and Special Collections Department at the University of Minnesota Libraries, and is one of four collegial collections on migration and social services. It's staff consists of 3 archivists within a department of 30, in the context of a university library of 320 staff members. This larger University Libraries is an integral part of its research university, the University of Minnesota, playing a strong role in campus life and contributing academic resources to the campus community. Other learners and researchers are also supported by the Libraries; over half the users of the Archives and Special Collections Department are from outside of the campus community, and due to our robust virtual reference service, a majority of the IHRCA's patrons are located around the world. The 
IHRCA preserves and provides access to a collection rich in multilingual primary sources, as well as multilingual secondary sources such as those collected by or authored by immigrants to North America. The IHRCA strives to connect past with the present and to engage with both local and global communities. It enjoys a reputation created and strengthened during the collections' management by the Immigration History Research Center between 1965 and 2013, and it was during this time period that the Estonia Minnesota project developed.

In 2013, the collections were transferred from the Center to the University Libraries, creating the "Immigration History Research Center Archives." The resources and structure of the university library benefitted collections and staff in many ways, such as increased access to centralized bibliographic, access, communication, and other library systems. One of these systems is the recently-adopted content management system in the Archives and Special Collections Department. This system, ArchivesSpace, internally manages standardized collection information throughout its lifecycle, and also shares descriptive information in the form of collection guides via a public user interface. Further, ArchivesSpace includes an open archives initiative protocol for this metadata, allowing for harvesting and indexing by other systems, a key element in today's web-based and broad array of discovery platforms.

The materials around which the Estonia Minnesota collaboration revolves are the manuscripts and archives of the IHRCA's Estonian American collection. This material comprises only a portion of the Archives, the larger scope of which includes many diverse diasporic, ethnic and identity groups dating from the second half of the nineteenth century through present day. The Estonian-related collection includes print matter such as books and serials, and a significant group of archival collections created by displaced or exiled Estonians, and later collected by the Estonian Archives of the US, Inc. (EAUS) in Lakewood, New Jersey. ${ }^{5}$ The bulk of this archival material was transferred to Minnesota in 2003. An archivist involved with the project since the beginning, Necas (2019) summarized this archival material as follows:

The creators and compilers of the materials were mostly refugees from Estonia who arrived in the United States as displaced persons in the late 1940 s and early 1950 s.... The materials often document the dramatic years of World War II and the flight of Estonians from their country occupied alternatively by Germany and the Soviet Union .... Many Estonians ultimately resettled in other parts of Europe, the United States and Australia....The collections also provide a detailed picture of the rich cultural and social life of the Estonian diaspora maintained by many organizations established around the United States and the world." (Necas, 2019; p. 247) 
From the perspective of the IHRCA, which preserves and provides access to these collections, it is important that this material be processed so as to improve discoverability and access for all users, and to connect it to other source material that shares a creator or provenance. The Estonia Minnesota project helps the IHRCA improve this curatorial knowledge of the material, by the augmentation of their staff with subject specialists from the National Archives of Estonia who are also fluent in the sources' languages.

The National Archives of Estonia (NAE) is the center of archival administration in the Republic of Estonia. It is a memory institution and also a government agency under the jurisdiction of the Ministry of Education and Research. During the Soviet occupation, the principles of traditional archival theory and everyday work broke down, and were replaced by Soviet ones until the re-independence of the Estonian Republic in 1991. 6 During the 1990s, independent management of the archives was restored, and the National Archives of Estonia became active in 1999 in accordance with the Archives Act. With a staff of 190, the NAE provides for the preservation of its nine million records dating from the thirteenth century to present, and devotes great attention to the development of online content and services. The majority of the collections are public records from state institutions, though the records of private institutions, personal archives, and expatriate cultural heritage are also collected. And while the NAE's diasporic material, including records of the Government in Exile and the Consulate General in New York (the Republic's carrier of legal continuity during the occupation years of 1940-1991) is small, it is valuable, and is almost fully processed and accessible. Expatriate and diasporic material, largely from Sweden as well as many other places including the U.S., is of high interest to the NAE, particularly within the last few decades.

Estonia's population, measuring just over 1 million people at the outset of World War II, ${ }^{7}$ was significantly depleted by $\sim 25 \%$ during that war, and it is estimated that 70,000+ left Estonia as war refugees and émigrés. Many of these traveled to Sweden and Germany, with the refugees later settling in Australia, Canada, Great Britain or the U.S., due to the Soviet occupation. This exile community became the carrier of the continuity of the Estonian Republic (Meerits, 2006). ${ }^{8}$ Estonian community-based archives abroad were founded by the 1960s in Australia, Canada, and the U.S. These soon became crucial memory and heritage sources for Estonians everywhere, for during this same period within Estonia, the totalitarian foreign occupation regime closed associations and private schools and businesses, private property was nationalized, and only Communist Party-controlled organizations were allowed. Mass deportations, further prohibitions, ideological pressure, and control 
during this time also included selective destruction of cultural heritage within libraries, museum closures, and archival records restrictions. Further, because at this time Estonia was politically, culturally and economically separated from the rest of the world, the refugees and their descendants living outside of Estonia continued the national cultural traditions and activities. ${ }^{9}$ This scarcity of diasporic cultural heritage material located in Estonia contributes to the strong interest in library and archives-related international collaboration, such as the NAE project with Minnesota. The goal is to build awareness of and availability to the history of the diaspora for those located around that diaspora, as well as to patrons in the homeland of Estonia.

After the transfer of EAUS collections to the University of Minnesota, and due largely to the friendly and ongoing relationships between the EAUS and the Minnesota staff, an idea developed to utilize the skills of Estonian archivists to increase understanding of the collections and improve access to them. In 2008 E. H. Hawley, then program director in the Immigration History Research Center, recognized the value of the Minnesota-based collections and the interest of the wider community, and consulted colleagues in Estonia. A plan developed through the vision and hard work of many, to describe the material and also link to known related material in other libraries, archives or museums. In 2009, the first NAE staff visited Minnesota to process collections. ${ }^{10}$

Related developments contributed to this possibility. As noted above, the changes in Estonia in the 1990s led Estonian archives, libraries and museums to begin collecting sources from the diaspora, and also heightened their interest in cooperating with communities and institutions around the globe. A transnational cultural heritage association, the Baltic Heritage Network (Balthernet), was founded in 2008 to foster cooperation between national and private archives, libraries, museums, and others invested in the cultural heritage of the Baltic diaspora. The Estonian Archives Working Group of Balthernet played (and continues to play) an important role within the Minnesota project, by launching and promoting it, and applying for financial support. Also, the Compatriots Program was founded by the Estonian Government in 2004; its third period (2014-2020) is currently in progress. This is a state program which aims at supporting Estonians living abroad by helping them preserve language skills, and maintain national culture and identity. The Compatriots Program also focuses on expatriate cultural heritage, including collecting, preserving and creating access, and as such, is a source of support for the NAE.

The first year of the Estonia Minnesota project was considered successful and mutually appreciated and beneficial, so the primary parties decided to continue the collaboration. A standard model developed 
wherein a team of two NAE archivists, selected with consideration for availability, language ability, and expertise (already held, or with a goal to expand or build expertise with non-governmental or diasporic material) visited the University of Minnesota for approximately a month. One was often a senior archivist and the other strong in database expertise. Costs of the collaboration from the beginning have been shared by both partners. NAE funding provides a slight majority of the necessary funds, covering the "Estonian-based" fees including airfare, salary, per diem, travel insurance, and U.S. embassy fees. IHRCA's funding source, a gift fund expressly for support of the Estonian American collections, provides for the U.S.based fees, namely lodging, in-country health insurance, visa, and a language test that helps us meet the English-language requirement for the Department of State's Exchange Visitor Program. The planning process currently takes about 6 months. First, administrators begin the process with expressions of mutual interest in continuing the project, and locating funds. Formal letters outlining contributions and agreement are written. Next, NAE staff commit to the project and make travel plans, and Minnesota begins a visa application process, working with the campus' international student and scholar services office. Human resources at both institutions also assist; in Minnesota, for example, the visiting scholars are officially registered as persons who hold an association outside of a defined appointment.

Then a collections processing plan is formed; the archivists at IHRCA suggest collections to be processed, based upon criteria such as user demand for the material or physical and space needs. NAE's interests as to which collections will be processed are usefulness to Estonian historians and other patrons, and linking Minnesota collections with those also found in and partly represented in Estonian institutions, or elsewhere in the world. (This latter goal is of interest to Minnesota, as well.) The administrators and archivists discuss this list via e-mail, and typically easily agree on them. Next, as the aim of the Estonians is always to describe as many collections as possible when onsite in the U.S., Estonian staff begin describing the record creators and locating related collections months before the visit. Minnesota staff physically prepare the collections and workspace, and upon welcoming the Estonian colleagues, train them in the ArchivesSpace system, and discuss internal processing procedures or any known issues with the materials. The Estonian staff enjoy the support of the Minnesotans while in the U.S., working as colleagues and collaborating where necessary or desired. While the program is not primarily a staff development or cross-training model, some development naturally occurs during the collaboration. 


\section{ANALYSIS AND REVIEW}

As a result, between 2009 and 2019 the staff from the National Archives of Estonia have arranged and described $\sim 350$ collections of personal papers and organizational records located in Minnesota. Researchers in Estonia are directed to Minnesota's search and discoverability tools, and to IHRCA staff for virtual or in-person access to the material. The project continues for the present and near future, as $\sim 25 \%$ of the collections received from the EAUS remain in need of processing. From the perspective of both partners, the collaboration is a great success, measured by the work accomplished and the improved discoverability due to over 300 additional collection guides now searchable through the ArchivesSpace system. This discoverability directly benefits staff and researchers in both countries. As stated by a scholar who has visited Minnesota many times to conduct research, "The valuable materials held in [the] IHRCA ... have become more accessible and have enabled not just me, but other scholars to complete studies that have really driven the academic conversation about the Estonian diaspora forward" (Merivoo-Parro to Ramler, personal communication, April 17, 2019). And true to the goals of the initial project planners, the creators of collections are linked when possible in the archival description; as shown in Figure 1, this linkage of rare material provides a great intellectual service to staff and to researchers alike.

The international colleagues have built new professional relationships, and skills are learned and shared. The IHRCA is particularly grateful for the multilingual skills of the visiting Estonians, who closely review the source material and provide the English language metadata. Challenges within the project include moderate financial challenges and the significant, though manageable, administrative investment as described above. For the NAE, the challenge lies in discharging one or two archivists for a month from their commitments, however, this challenge is balanced by the experiences gained from this project, as it offers a great training opportunity for NAE staff who might not yet have experience with diaspora collections. From the Estonian perspective, the NAE's duty is to contribute to the accessibility of the Estonian diaspora collections and it has been a professional pleasure for the staff of the NAE to work with these great collections. For the IHRCA, the administrative investment is in pretrip planning and a complex visa application process, as well as in the content management system training and significant collection management during the visit. Finally, there is obvious time commitment involved by all parties during the month of the intense processing work. Overall the experience is both culturally and professionally positive for the hosts and the visitors. As a result of the project's success, the NAE is 


\section{RELATED COLLECTIONS}

Personal collection in the National Archives of Estonia: ERAF.9616; Personal collection in the Estonian Archives in Australia

Finding Aid \& Administrative Information

Collecting Area Details

\section{Collection organization}

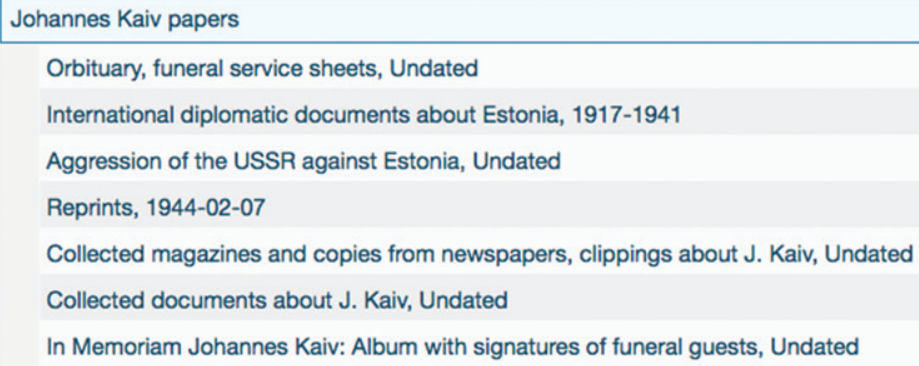

FIGURE 1 A portion of a collection guide to the Johannes Kaiv papers in Minnesota, showing the known related collections located in Estonia and Australia.

reproducing this model with another North American institution, the Museum of Estonians Abroad (Toronto, Canada), launching a similar project in 2018.

\section{CONCLUSION}

A decade's work to improve access to Estonian diasporic historical source material continues to meet both the individual and shared goals of its partner institutions. Thus, the Estonia Minnesota project provides one model for building international access to the rare source material. While other recent and current projects are described in the literature stress staff development or exchange, and digital surrogates, this project centers on greater global 
discoverability through archival description, and this article shares some of the administrative details involved with the project. Further, it contributes to the small amount of published library literature centered in migration; the project honors and responds to the cultural and informational migration that both formed the material and that drives current information demand. By collaborating across borders, the combined assets of two very different institutions enable specialized staff to work together and improve global access.

\section{NOTES}

1. Processing is defined by the Society of American Archivists as "The arrangement, description, and housing of archival materials for storage and use by patrons." Retrieved February 27, 2019, from https://www2.archivists.org/glossary/terms/ $\mathrm{p} /$ processing

2. Archives Act of Estonian Republic. Retrieved March 11, 2019, from https://www. riigiteataja.ee/en/eli/ee/504032016002/consolide/current

3. Archival Rules. Retrieved March 11, 2019, from http://www.ra.ee/wp-content/ uploads/2016/12/archival_rules_annexes.pdf

4. ISAD $(G)$ : General International Standard Archival Description - Second edition. Retrieved March 11, 2019, from https://www.ica.org/en/isadg-generalinternational-standard-archival-description-second-edition

5. The Estonian Archives in the US, Inc. was established by Estonian organizations in 1969. In addition to archival collections there are a library, collections of art, periodicals, photographs, multimedia, insignia and artefacts, as is found in other community-based Estonian archives around the world. In spite of the annex built in the 1980s, the lack of space became a major problem for the EAUS in 1990s, and is a major reason for the agreement made in 2003 for more than 1000 linear feet of material to be transferred from the EAUS to the then-Immigration History Research Center. Run by volunteers, the EAUS is still an active community archive and is, at the time of this publication, open for patrons four hours per week. Noorhani (2008) notes them as one of the world's five major Estonian collections outside of Estonia; Kreslins (2002) called them "an outstanding repository of both printed and manuscript materials whose purpose is to document the Estonian experience in the United States" (p. 203). Also see Wurl (2005), and http:/ / eausa.balther.net/, Retrieved February 28, 2019.

6. For more information see, Pirsko (2018).

7. Population in counties and towns, 1934. Statistics Estonia, Retrieved April 23, 2019 from https://www.stat.ee/26396.

8. The history of information sources as well as people is complex. Due to the proximity of Sweden to the Soviet Union, both personal papers and state documents of Estonians living in Sweden were later deposited with the Swedish state archives. Also, the Baltic Archives, an independent archives, was founded there in 1968, with strict access regulations. The holdings in the Baltic Archives included the so-called core documents of Estonian independence dating from 1918, having been secretly delivered to Sweden before the first Soviet occupation in 1940. In 2001, these documents were returned to the Estonian Republic by the Baltic Archives. For further reading, see http://galerii.kirmus.ee/baltic_archives_ abroad_2006/kogumik/eng/Meerits.htm, Retrieved February 28, 2019. 
9. For more information, see Kreslins (2002), Lepik (2014), Noorhani (2008) and Wurl (2005).

10. For more on this history, see Necas (2019).

\section{ACKNOWLEDGEMENTS}

The authors would like to acknowledge the many people through the years and at present who formed and contribute to the project described in this article.

\section{REFERENCES}

Asencio, M. (2017). Collaborating for success: The digital library of the Caribbean. Journal of Library Administration, 57(7), 818-825. doi:10.1080/ 01930826.2017 .1362902

Evans, F. (1987). Promoting archives and research: A study in international cooperation. The American Archivist, 50, 48-65. doi:10.17723/ aarc.50.1.4410875101q48139

Farrugia, C. (2018). Lone Rangers no more: Archival cooperation in transition. Comma, 2016(1-2), 115-124. doi:10.3828/comma.2016.11

Jihua, Z. (2015). Archival exhibitions: Cross-border cultural exchange and collaboration. Comma, 2014(1-2), 179-184. DOI: 10.3828/comma.2014.15.

Kreslins, J. A. (2002). Collections of Baltic vernacular-language publications at some North American libraries: An attempt at a survey. Slavic \& East European Information Resources, 3(2/3), 201-216. doi:10.1300/ J167v03n02_21

Lepik, A. (2014). An ongoing process of modernization: Libraries and librarianship in Estonia. Library Trends, 63(2), 183-196. doi:10.1353/lib.2014.0029

Li, X. and W. Pan (2018, June). Scaling and sustaining international partnerships a case study. IATUL Annual Conference Proceedings, Oslo, Norway, Paper 4, pp. 1-8. Retrieved from https://docs.lib.purdue.edu/iatul/2018/collaboration/ 4

Little, H. (2007). Archive fever as genealogical fever: Coming home to Scottish archives. Archivaria, 64, 89-112.

Mattson, M. and J. Hickok (2018). International library partnerships: From shoestring startups to institutional sponsorships. portal: Libraries and the Academy, 18(4), 639-650. doi:10.1353/pla.2018.0038

Matusiak, K.K. (2017). User navigation in large-scale distributed digital libraries: The case of the Digital Public Library of America. Journal of Web Librarianship, 11(3-4), 157-171. doi:10.1080/19322909.2017.1356257

Meerits, K. (2006). Baltic archives in exile and today. In International Conference on the Baltic Archives Abroad 2006 Article and Papers. Retrieved from http://galerii.kirmus.ee/baltic_archives_abroad_2006/kogumik/eng/Meerits. htm 
Necas, D. (2019). International collaborations at the immigration history research center archives (IHRCA). In L. I. Carpenter \& Y. Luckert (Eds.), The globalized library: American academic libraries and international students, collections, and practices (pp. 245-260). Chicago, IL: Association of College and Research Libraries, a division of the American Library Association.

Noorhani, P. (2008). Networking the cultural heritage of the Estonian Diaspora: Attempts and experiences. Knygotyra, 50, 236-243. doi:10.15388/ kn.v50i0.7925

Pirsko, P. (2018). Das Archivwesen in Estland. Archivar, 71(3), 250-256.

Smith, B. J. (2015). The case for international collaboration in academic library management, human resources and staff development. IFLA Journal, 41(2) 140-152. doi:10.1177/0340035215580140

Smith, B. J. (2016). Broadening our scope: International collaboration for retooling the academic library. Journal of Library Administration, 56(4), 395-415. doi: 10.1080/01930826.2016.1144929

Somerville, M. M., Cooper, L., Torhell, C., \& Hashert, C. (2015). At home in the world: International library staff exchange program highlights. IFLA Journal, 41(4), 326-335. doi:10.1177/0340035215596348

Wurl, J. (2005). Documenting displacement: The migration of archival sources from post-WW II East European Émigré Groups. Archival Science, 5, 79-92. doi:10.1007/s10502-005-5763-X

Yakel, E. (1992). Pushing MARC AMC to its limits: The Vatican archives project. The American Archivist, 55(1), 192-201. doi:10.17723/ aarc.55.1.32306858j28557h1 